\title{
Nutritive Values of the Leaves of Crescentia Cujete (Ugbuba)
}

\author{
Umudi E. Queen \\ Correspondence: Umudi E. Queen, College of Education, P.M.B. 2090, Abgor, Delta State, Nigeria.
}

Received: May 5, 2019 Accepted: July 14, 2019 Online Published: August 1, 2019

doi:10.5539/ijc.v11n2p106

URL: https://doi.org/10.5539/ijc.v11n2p106

\begin{abstract}
Mineral and proximate analysis of Crescentia Cujete (Ugbugba) leaves were examined using the methods recommended by Association of Official Analytical Chemist (AOAC). The leaves contained $51.00 \pm 1.05 \%$ moisture, $2.30 \pm 0.2 \%$ ash, crude protein $51.00 \pm 0.43 \%$, crude lipid $1.90 \pm 0.08 \%$, crude fibre $4.00 \pm 0.12 \%$, carbohydrates $40.40 \pm 0.02 \%$. The minerals ranges from $\mathrm{mg} / \mathrm{g}$ dry weight $\mathrm{K}(30.02 \pm 0.03), \mathrm{Na}(12.10 \pm 0.32), \mathrm{Ca}(60.00 \pm 0.01) . \mathrm{Mg}$ (361.42 \pm 0.01$), \mathrm{P}(14.19 \pm 0.42), \mathrm{Mn}(6.32 \pm 1.01), \mathrm{Fe}(2.43 \pm 0.01), \mathrm{Cu}(13.04 \pm 0.10), \mathrm{Zn}(1.20 \pm 0.43), \mathrm{Na} / \mathrm{K}(0.40)$ and $\mathrm{Ca} / \mathrm{P}$ (2.14), K, Mg, Ca and Fe were found in significant concentrations. The findings showed that Crescentia Cujete leaves are source of nutrients for edible purpose, a good $\mathrm{Na} / \mathrm{K}$ ratio for lowering blood pressure.
\end{abstract}

Keywords: composition, Crescentia Cujete, elemental analysis, mineral, nutrient, proximate

\section{Introduction}

Nutritional transition due to adaptation to junk foods was identified as one of the factors responsible for underutilization of wild leaves vegetables in urban environments of developing countries (Ganry, 2008). It is well acknowledged that some diseases such as diabetics, cancers, obesity and cardiovascular diseases are associated with inadequate consumption of fruits and vegetables. This increase in people living with diabetes is attributed to intake of refined food as symbol of well being, as substitute to locally available food minerals particularly wide vegetables leaves) which are considered as "food for the poor" are rich sources of minerals, vitamins, fibre, amino acids and antioxidants, (Itanna, 2002).

Medicinal plants have been in use for the eradication of human suffering since ancient times. In light of their therapeutic efficiency, the pharmaceutical industries started the crude extraction of medicinal plants for drugs manufacturing (Anyasor, Anna, Olushola \& Aniyikaye, 2011). Phenolic compounds, flavonoids, derivatives of anthraquinone, anthocyanins, tannis, alkaloids which are secondary metabolites because of their phytochemical components present are responsible for their effectiveness. For the proximate and mineral composition, it can protect human against various diseases and ailments and affects its nutritional properties which could be used to rationlise the indigenous use of Crescentia Cujete as supplement. These phytochemicals present in vegetables are believed to be responsible for prevention of the above mentioned diseases (Kala \& Prakash, 2006).

Calabash tree is a tropical large tree planted in temperate region and southern part of Nigeria. It belongs to the family of Bignonia ceae and it is botanically known as Crescentia Cujete or Igisogba. It is propagated by either seed or by stem cuttings. It is a tree that grows to $6 \mathrm{~m}$ high, the leaves are simple and shaped like spatula and pointed. They are arranged in cluster around the stem. The flowers are $1-2 \mathrm{~cm}$ long and yellowish corolla, with red or purple veins arising from truck or main branch and blossom at night. It produces a large green gourd like fruit which is globulose with a smooth hard green woody shell. The fruit is up to $12-14 \mathrm{~cm}$ in diameter and takes about 5 months to mature and fall to the ground. The fruit has a white pulp and small flat seeds that are embedded in the pulp.

In herbal medicine, the fruit is used as oral anti-tumor, anti-diarrhea, a ganglioma inflammation (Minor, 2007). The fruits and leaves are used in treating fever, respiratory track complaints, hypertension, (Hassan, Mshaelia, Umar \& Ogbiko, 2018). Some studies have reported the wound healing, haemostatic, anti-rheumatism, anti-bacteria, hipatoprotective, stomach ache, respiratory tract disorder, cataract as well as protection against $\mathrm{CCl}_{4}{ }^{-}$induced liver damage (Dhawan \& Gupta, 2017). The unripe fruits have been used as laxative, antipyretic and for cough. The leaves are air dried, grounded and taken as Africa tea twice daily.

The purpose of this study is to determine the nutritive values of the leaves of the nutritive values of the leaves by evaluating the proximate and mineral compositions, the $\mathrm{Na} / \mathrm{K}$ and $\mathrm{Ca} / \mathrm{P}$ ratio as a source of food that can lower blood pressure. 


\section{Materials and Methods}

Calabash plant (leaves) were obtained from Agbor, from four different sources, were mixed to form a representative sample of the leaves which is the administrative headquarter of Ika South Local Government Area, Delta State. It is located in the Northern part of the Niger Delta, within the coordinates of latitude $6^{\circ} 07^{\prime} \mathrm{E}$ to $6^{\circ} 06^{\prime} \mathrm{N}$ to $6^{\circ} 16$ and latitude $6^{\circ} 07$ to $6^{\circ} 12^{\prime} \mathrm{E}$. They were air dried and milled to fine powder, sieved through $20 \mathrm{~mm}$ mesh and packed in labelled sample bottles. Those for moisture determination were put in polyethylene bags to prevent loss of moisture during transportation to the laboratory. The leaves were dried at $60^{\circ} \mathrm{C}$ for 24 hours (Aguye, Urga, Knapp, Selmar, Omwega, Imungi \& Winterhalter, 2003).

\section{Proximate Analysis}

The methods recommended by the Association of Official Analytical Chemistry (AOAC, 1990) were used for the determination of ash, crude lipid, crude fibre and nitrogen contents.

Crude protein was estimated by multiplying the values obtained for percentage nitrogen by a factor of 6.25 . Five grams of fresh leaves were weighed and oven dried (Gallenkamp UK 10) at $105^{\circ} \mathrm{C}$ for 24 hours and cooled in a desicator and weighted. The weight loss was expressed as percentage of moisture content.

Ash content was determined by incinerating $5 \mathrm{~g}$ of leaves powder in a muffle furnace (Lenton, England), at $700^{\circ} \mathrm{C}$ for 4 hours and its weigh expressed as percentage of ash content. Carbohydrates was estimated by subtracting, lipid, proteins, crude fibres and ash from $100 \%$ dry weight of the leaves.

Mineral analysis was done by wet digestion method using $1 \mathrm{~g}$ of the leaves powder with trioxonitrate (v) acid, per chloric/tetraoxo sulphate (vi) acid. Phosphorus was determined by vanado-moybdo phosphoric acid colorimeter. Sodium and potassium were determined using corning 600 flame photometer, while other metals were analysed using spectral -10 Atomic Absorption spectrophometer.

\section{Results and Discussion}

Table 1. Proximate composition of calabash plant leaves(\%)

\begin{tabular}{ll}
\hline Parameters & Concentration \\
\hline Moisture contents & $50.00 \pm 1.05$ \\
Ash content $(\% \mathrm{dw})$ & $2.30 \pm 0.02$ \\
Crude protein content & $51.00 \pm 0.43$ \\
Crude lipid content & $1.90 \pm 0.08$ \\
Crude fibre content & $4.40 \pm 0.12$ \\
Carbohydrate content & $40.40 \pm 0.40$ \\
\hline
\end{tabular}

Table 2. Composition of mineral in calabash plant leaves

\begin{tabular}{ll}
\hline Mineral Element & Quality mg/100g \\
Potassium (K) & $30.02 \pm 0.03$ \\
Sodium (Na) & $12.10 \pm 0.32$ \\
Calcium (Ca) & $60.00 \pm 0.10$ \\
Magnesium (Mg) & $361.42 \pm 0.01$ \\
Phosphorous (P) & $14.01 \pm 0.42$ \\
Manganese (Mn) & $6.33 \pm 0.01$ \\
Iron (Fe) & $2.43 \pm 0.01$ \\
Copper $(\mathrm{Cu})$ & $13.04 \pm 0.10$ \\
Zinc & $1.20 \pm 0.43$ \\
$\mathrm{Na} / \mathrm{K}$ & 0.40 \\
$\mathrm{Ca} / \mathrm{P}$ & 2.14 \\
\hline
\end{tabular}

Table 1 showed the proximate composition of calabash plants (leaves). It has a high moisture content of $50.00 \pm 1.05$ by weight which is comparable with that obtained by (Edema, Iyakoha, Oheri \& Tomori \& Obiole, (2000), Calvet \& Locett (2002) and George, (2007). The high moisture content makes the leaves highly susceptible to microbial attack. 
The ash content values were $2.30 \pm 0.21 \%$ compare with that recorded for Selenium americium leaves which was lower (Hassand \& Umar, 2007). The ash content suggests it could provide essentials valueable and useful minerals needed for good body development. The protein content $51.00 \pm 0.43$ indicates that the leaves could be good source of proteins. The major drawback of the use of vegetables in human nutrition is the fibre content, which often causes intestinal irritation and their low nutrient bioavailability (Kumar, 2014).

The crude lipid content $1.90 \pm 0.08 \%$ was low as most leafy vegetables have low lipid contents. But it can still serve as protein supplement (Ali, 2011). The estimated carbohydrate content was lower compared to some vegetables like Senaobuusfolia leaves, it is not a source of calories. The crude fibre was lower compared with Senafolia leaves (Aremu, Olomisaki, Otene \& Atolaiye, 2005).

Table 2 showed the composition of mineral in leaves of calabash plat. The result showed that the leaves are important sources of iron, potassium ad calcium. The Iron $2.43 \pm 0.01 \mathrm{mg} / \mathrm{g}$ is considered significant from the $1.00 \mathrm{mg} / 100 \mathrm{~g}$ recommended daily intake (Yang, Hov, Mei \& Lin, 2007). Calcium content was low $60.00 \pm 0.10$. Also iron deficiency is the most prevalent nutritional deficiency in human. (Lubbork, Clark \& Goldman, 2004). Magnesium 361.42 \pm $0.01 \mathrm{mg} / \mathrm{g}$ is the second most abundant mineral present in the sample. It was about the recommended daily allowance (RDA) of $350 \mathrm{mg} / 100 \mathrm{~g}$. It helps in calcium metabolism in bones and is involved in prevention of circulating diseases. It is a rich source of magnesium to the body.

The zinc level is low $1.20 \pm 0.43 \mathrm{mg} / \mathrm{g}$, zinc is necessary for the growth and multiplication of cells (enzymes responsible for DNA and RNA synthesis) for skin integration, bone metabolism and function taste and eye sight (Kumar, 2014). Zinc and magnesium constitute prosthetic group of enzymes in body metabolism and its deficiency can retard growth of enzymes in body metabolism and its deficiency can retard growth (Omole, 2003). Na/K ratio in the human body controls high blood pressure (Onimawo Oteno, Orokpo \& Akubor, 2008). Foods with Na/K ratio less than 1 has impact of lowering blood pressure. The value of $\mathrm{Ca} / \mathrm{P}$ ratio is 2.14 which is considered to be good food source, since the $\mathrm{Ca} / \mathrm{P}$ ratio is above 1 and poor when $\mathrm{Ca} / \mathrm{P}$ ratio is less than $0.5 \mathrm{mg} / 100 \mathrm{~g}$.

Copper is also an essential component of many redox enzymes, including cytochromic oxidase. It essential for the formation of haemoglobin of the red blood cells. It is required in trace quality of 900ug. Its deficiency results in anemia like symptoms.

\section{Conclusion}

The result shows that calabash plants (leaves) are good sources of protein and carbohydrates. The leaves are rich sources of magnesium needed for bone development and rich in mineral elements needed for development and rich in micro elements needed to combat disease and impact of lowering blood pressure.

\section{References}

Abuye, C., Urga, K., Knapp, H., Selmar, D., Omwega, A. M., Imungi, J. K., \& Winterhalter, P. (2003). A Compositional Study of Moringa Stenoptela Leaves. East African Medical Journals, 80(5), 247-252. https://doi.org/10.4314/eamj.v80i5.8695

Ali, A. (2011). Physicochemical and Nutritional potential survey of plant food obtained from India. World journal of Science and Technology, 1(2), 34-38.

Alinnor, I. J. (2007). Preliminary Phytochemical and Antibacterial Activity. America Journal of Clinical Pathology, 45, 492-493.

Anyaso, G. E., Ama, M., Olushola, A. F., \& Aniyikaye (2011), Phytochemcial constituten, prosimate analysis, andtioxidant, antibacterial and wound healing propertices of lead extract of chromolaena adorata. Annal of Biological Research, 2(2), 441-451.

AOAC (1990). Official Methods of Analysis (14th edition) Association of official Analytical chemical USA, Washington, DC.

Aremu, M. O., \& Olomisaki, A, Otene, I. W., \& Atolaiye, B. O. (2005). Mineral content of some Agricultural products grown in the middle bet of Nigeria. Oriental Journal of Chemistry, 21(3), 419-426.

Dhawan, D., \& Gupta, J. (2017). Composion of different solvents for extraction potentials from Datura metal plant leaves. International Journal of biological Chemistry, 11, 17-22. https://doi.org/10.3923/ijbc.2017.17.22

Edema, M. O., Iyeko, O., Oheri, E., \& George, G. E. (2007). Chemical and Antimicrobial screening of some medical plants chemical Journal, 3, 635-639.

Ganry, J. (2008). Promotion of fruits and vegetables in countries of sub-saharan Africa and the Indian Ocean. Fruits, 63, 63. https://doi.org/10.1051/fruits:2008002 
Hassan, L. G., Mshellia, H. E., Umar, K. J., Umar, U. A., \& Ogbiko, C.(2018). Isolation and chatacterization of ccccc amyrin and cccc sitasterel from Ethyl Acetate Extract of the leaves of monechma ciliatum (Jacquin). International Journal of Pharmacy and Pharmaceutical Research, 12(1), 298-306.

Itanna, F. (2002). Metals in leafy vegetables grown in Addis Ababa and toxicological implications. Ethiopian Journal of Health Development, 6(3), 295-302. https://doi.org/10.4314/ejhd.v16i3.9797

Kala, A., \& Prakash, J. (2006). The comparative evaluation of the nutrient composition and sensory attributes of four vegetables cooked by different methods. International Journal of Food Science and Technology, 41, 163-171. https://doi.org/10.1111/j.1365-2621.2005.01043.x

Kumar, S. (2014). The importance of antioxidants and their role in pharmaceutical science - a review Asian Journal of Research in chemistry and Pharmaceutical Science, 1(1), 27-44.

Labbok, M. A., Clark, D., \& Goldma, A. S. (2004). Breastfeeding maintaining an irreplaceable immunological resource. Nat. Rev. Immunut., 4, 565. https://doi.org/10.1038/nri1393

Lockett, C. T., Calvert, C. C., \& Grivetti, L. E. (2000). Energy and mieronutrient composition of dietary and medicinal wild plants consumed during drought. Study of rural Fulani, northeastern Nigeria. International Journal of Food Science and Nutrition., 51(3), 195-208. https://doi.org/10.1080/09637480050029700

Okerulu, I. O., \& Ani, C. J. (2001). The Phytochemical Analysis and Antibacterial screening of Extracts of Tetracarpidium Conophorum. Journal of Chemical Society of Nigeria, 26(1).

Omole, S. O. (2003). The chemical composition of Caeselphnia puicherima. Nigeria Journal of Animal Production, 30(1), 15-19. https://doi.org/10.4314/njap.v30i1.3308

Onimawo, 1. A., Oteno, F., Orokpo, G., \& Akubor, P. I. (2003). Physicochemical and nutrient evaluation of African bush mango (frvingia gabonensis) seeds and pulp. Plant Foods for Human Nutrition, 58(3), 1-6. https://doi.org/10.1023/B:QUAL.0000040320.33549.df

Tomori, W. B., \& Obijole, O. A. (2000). Mineral for facilities provided composition of some less utilized vegetables in. Nigeria. Afr. J. Sd. Tech., 1, 153-157

WFIO/FAO (1985). Report, Energy and protein requirement WHO technical report series, 724, 220.

Yang, H., Hov, A. J., Mei. S. X., \& Lin, Z. W. (2007). Constituents of clerodendron bungei. Journal of Asia Natural products research, 4, 165-169. https://doi.org/10.1080/1028602021000000053

Yusuf, A. A, Moflo, B. M., \& Ahmed, A. B. (2007). Proximate and mineral composition of Tamandious Indice linn 1753 seed. Science World Journal, 2(1), 1-4. https://doi.org/10.4314/swj.v2i1.51699

\section{Copyrights}

Copyright for this article is retained by the author(s), with first publication rights granted to the journal.

This is an open-access article distributed under the terms and conditions of the Creative Commons Attribution license (http://creativecommons.org/licenses/by/4.0/). 